ppi $201502 Z U 4645$

Esta publicación científica en formato digital es continuidad de la revista impresa ISSN-Versión Impresa 0798-1406 / ISSN-Versión on line 2542-3185Depósito legal pp $197402 Z$ U34
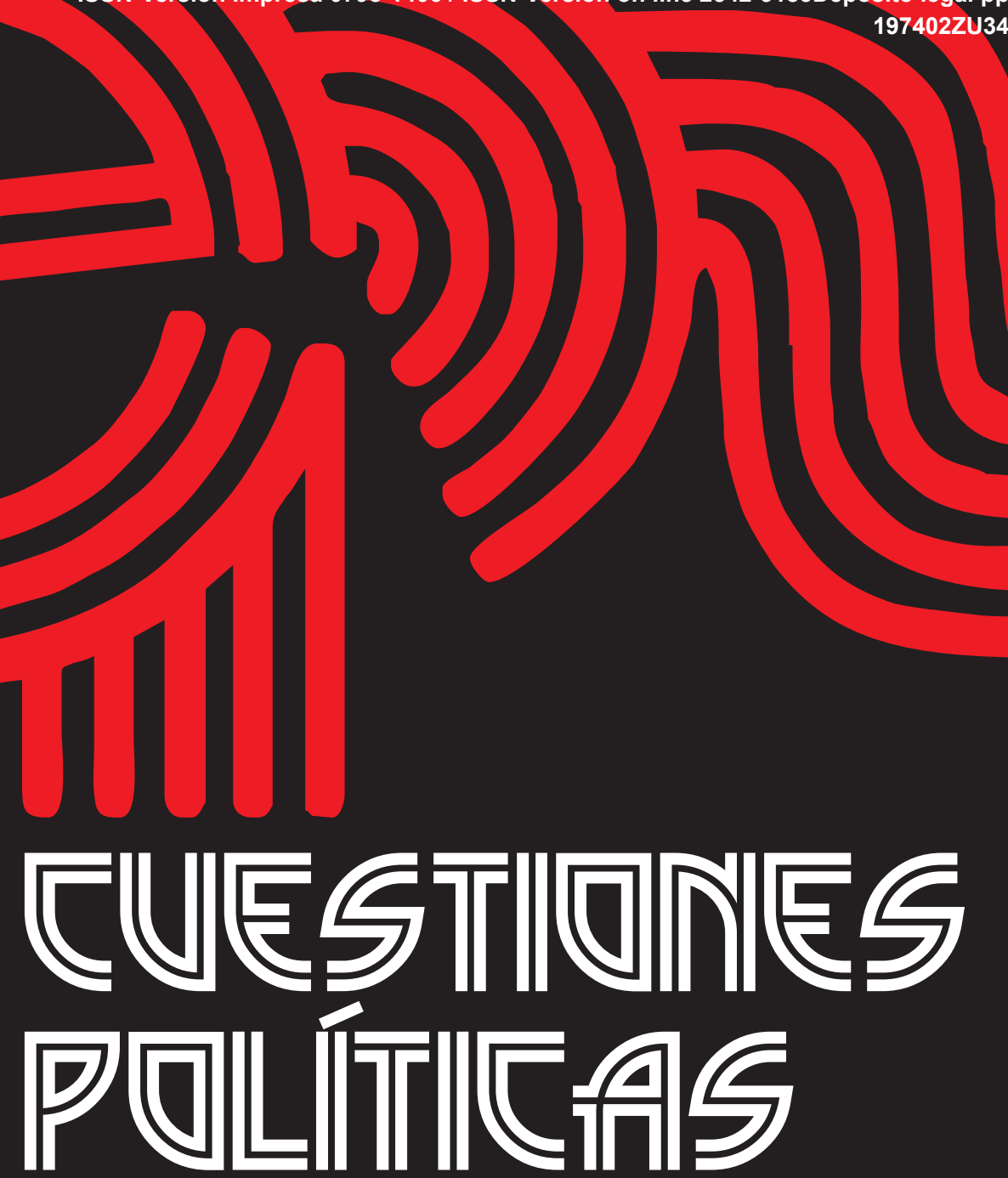

Instituto de Estudios Políticos y Derecho Público "Dr. Humberto J. La Roche" de la Facultad de Ciencias Jurídicas y Políticas de la Universidad del Zulia Maracaibo, Venezuela
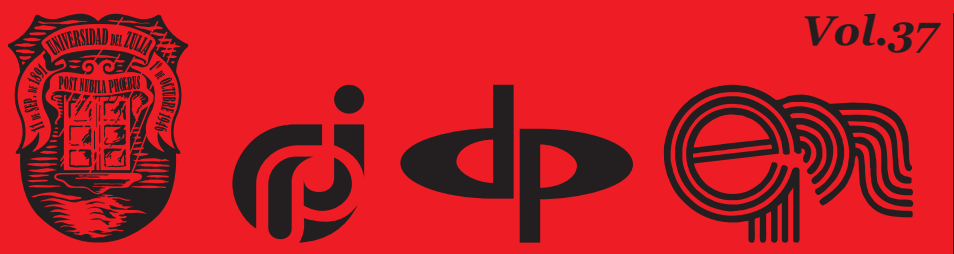

\title{
No 65
}

Julio

Diciembre 


\title{
Improving the State Regulatory System of the Agribusiness
}

\section{https://doi.org/10.46398/cuestpol.3865.09}

\author{
Zoya Ivanovna Latysheva * \\ Elena Viktorouna Skripkina ** \\ Natalia Alekseevna Kopteva *** \\ Dmitri Ivanovich Zhilyakov **** \\ Andrey Igorevich Nikiforov $* * * * *$
}

\section{Abstract}

The article aims to improve the state agribusiness regulatory system. It is established that the state regulatory system for agribusiness must be based on the application of a reasonable protectionism policy, guaranteeing food security through a system of tariffs and customs taxes on imported food products. The authors demonstrate the need to create a favorable climate for foreign investors, establish joint ventures in the agricultural business, provide state guarantees to foreign creditors by importing advanced equipment and technology, as well as finance key areas of science on business problems. agricultural. The theoretical and methodological basis of this study is an abstract logical method, induction, deduction, analysis, synthesis and systematization methods; as well as the statistical, economic and graphic methods used to study the levels and trends of change in the parameters of agricultural development in the current stage. In conclusion, it is revealed that parities in agricultural prices must include parity with

* Candidate of Economical Sciences. Federal State Budget Educational Establishment of Higher Educationm «Kursk State Agricultural I.I. Ivanov Academy» (FSBEE HE Kursk SAA), 70, Karl Marx Street, Kursk, 305021, Russia. ORCID ID: https://orcid.org/oooo-0002-6196-8969. E-mail: latysheva.z.i@mail.ru

** Candidate of Economical Sciences. Federal State Budget Educational Establishment of Higher Educationm «Kursk State Agricultural I.I. Ivanov Academy» (FSBEE HE Kursk SAA), 70, Karl Marx Street, Kursk, 305021, Russia. ORCID ID: https://orcid.org/oooo-0003-2222-636. E-mail: skripkina.e.v@bk.ru

*** Candidate of Technical Sciences. Federal State Budget Educational Establishment of Higher Educationm «Kursk State Agricultural I.I. Ivanov Academy» (FSBEE HE Kursk SAA), 70, Karl Marx Street, Kursk, 305021, Russia. ORCID ID: https://orcid.org/oooo-0002-1550-6093. E-mail: kopteva.n.a@mail.ru

**** Candidate of Economical Sciences. Federal State Budget Educational Establishment of Higher Educationm «Kursk State Agricultural I.I. Ivanov Academy» (FSBEE HE Kursk SAA), 70, Karl Marx Street, Kursk, 305021, Russia. ORCID ID: https://orcid.org/oooo-0002-7577-4639. E-mail: zhilyakov.d.i@mail.ru

*****Andrey Igorevich Nikiforov. Moscow State Institute of International Relations (MGIMO University), 76, Vernadskogo Prospect, Moscow, 119454, Russia. ORCID ID: https://orcid.org/oooo-0003-31125378. E-mail: a.i.nikiforov@bk.ru

Recibido: 12/04/2019.

Aceptado: 11/06/2019. 
consumer prices. for rural residents. The wages of employees in rural areas must guarantee the reproduction of the labor force and the development of the social sphere.

Keywords: state regulation of agribusiness; parity economy; state guarantees; farming; agricultural products.

\section{Mejoramiento del sistema regulador estatal de los agronegocios}

\section{Resumen}

El artículo apunta a mejorar el sistema regulatorio estatal de los agronegocios. Se establece que el sistema regulador estatal de los agronegocios debe basarse en la aplicación de una política de proteccionismo razonable, garantizando la seguridad alimentaria a través de un sistema de aranceles e impuestos aduaneros sobre los productos alimenticios importados. Los autores demuestran la necesidad de crear un clima favorable para los inversores extranjeros, establecer empresas conjuntas en el negocio agrícola, proporcionar garantías estatales a los acreedores extranjeros al importar equipos y tecnología avanzada, así como financiar áreas clave de la ciencia sobre los problemas del negocio agrícola. La base teórica y metodológica del presente estudio es un método lógico abstracto, métodos de inducción, deducción, análisis, síntesis y sistematización; así como los métodos estadísticos, económicos y gráficos utilizados para estudiar los niveles y tendencias de cambio en los parámetros de desarrollo agrícola en la etapa actual A modo de conclusión se revela que las paridades en los precios agrícolas deben incluir la paridad con los precios al consumidor para los residentes rurales. Los salarios de los empleados en las zonas rurales deben garantizar la reproducción de la fuerza de trabajo y el desarrollo de la esfera social.

Palabras clave: regulación estatal de agronegocios; economía de paridad; garantías estatales; agricultura; productos agrícolas.

\section{Introduction}

One of the ways to overcome the crisis in the Russian Federation is to strengthen state regulation of the agribusiness. Therefore, to counteract negative processes in the development of agribusiness, it is necessary to implement measures to stabilize agro-industrial production. The 
Zoya Ivanovna Latysheva, Elena Viktorovna Skripkina, Natalia Alekseevna Kopteva, Dmitri Ivanovich Zhilyakov y Andrey Igorevich Nikiforov

main efforts in planning and forecasting the effective operation of the agribusiness should be focused at the regional level. This work is already ongoing, and certain results have been reached so far. Thus, a system of budget subsidies for livestock products supplied for state needs has been already implemented; subsidies to support elite seed breeding have been allocated, partial compensation of agricultural organizations' costs for the purchase of mineral fertilizers and chemical plant protection products, feed, and other resources has been provided.

At the same time, due to insufficient budget funds, it is important to concentrate financial resources in the most important strategic areas, i.e. in those sectors of agricultural production where one can count on a relatively rapid increase in production, and maximum profit. Work should be done where there are opportunities to displace food imports and occupy this niche of the food market. These industries should primarily include the production of vegetables, fruits, feed, milk, and dairy products, as well as pig farming, poultry farming, and fish farming.

The study of issues related to the development of the agribusiness is reflected in the works of N.F. Kolesnik et al. (2020), Ya.V. Maltseva (2019), Yu.Ya. Rakhmatullin et al. (2020), E.G. Semyashkin (2019), A.S. Teunaev (2019), R.R. Yunyaeva and Klemanov (2020), and other authors. At that, currently, there are no clear determinants of the state regulatory system, whose definition would determine the development prospects of the agribusiness for a long period.

\section{Methods}

The theoretical and methodological basis of the present study is an abstract-logical method, methods of induction, deduction, analysis, synthesis, and systematization, used to justify approaches to modeling agribusiness development; as well as statistical-economic and graphical methods used to study the levels and trends of change in agriculture development parameters at the current stage.

The information base of the article includes statistical data of state bodies, legislative and regulatory documents governing the economic and legal aspects of the agricultural products market regulation, assessment of the effectiveness of the agribusiness under recessional conditions, as well as the results of conducted scientific research (Demkina, Kostikov, Lebedev, 2019; Nikolskaya et al., 2018; Shakhmametev, Strelets, Lebedev, 2018).

In the course of the study, it is planned to systematize the economic aspects of agribusiness functioning, develop measures for coordination of activities between the main players in the agricultural products market, 
improve the Russian model of agribusiness, and determine its individual features in the current context.

\section{Results}

Studies show that an important component of the country's agribusiness is the food industry, which is potentially the most flexible, quickly restored, and organized production. The food market is vital for ensuring the health and capacity of the nation and stimulating the development of other industries. Therefore, success or failure in meeting consumer demand for food products has clear political consequences.

Under these circumstances, Russia cannot receive foreign exchange resources regularly and in the required volumes which are necessary for updating and developing the technological base of the food industry. At the same time, one of the country's strategic priorities should be the production of a full range of equipment that would meet the highest contemporary requirements, which the food industry urgently needs. The food industry is still characterized by the highest investment attractiveness.

Besides, the development of food and processing industries is an essential condition for the country's economy to recover from the socioeconomic crisis. Solving this problem objectively requires strengthening state regulation of economic and financial processes without abandoning the general course of market transformation, and ensuring an unconditional balance of supply and demand in the consumer market. To meet the needs for technical resources, it is necessary to create conditions for the development of capacities of those organizations which provide tractors and agricultural machinery taking into account the zonal specifics and demand. Relevant unions, the development of leasing activities, and their demonopolization can play an important role in this process.

For rational use of state financial resources directed to the development of the material and technical base of the agribusiness, it is necessary to concentrate them in the existing special fund. The use of means from the state leasing fund will be made with the mandatory involvement of private financial resources and the selection of operators on a competitive basis. Part of the leasing fund should be allocated for equipping machinetechnological stations.

With international corporations developing the Russian market, there is a need to advance the production of spare parts moving the maximum portion of the production process to the territory of Russia. As for agricultural producers, they have been granted significant tax benefits. Preferential tariffs have been established for electricity used by agricultural organizations and enterprises for production needs, as well as restructuring 
processes and deepening the specialization of agro-industrial production dictated by market demand in the food market are being carried out.

Agricultural producers are increasingly adapting to market conditions. In recent years, the acreage for wheat, which is the main food crop, has been expanded. An issue of rational filling of crop rotations with crops, such as sugar beet, soy, corn, and perennial grasses is currently disputed. Despite economic woes, work is underway to implement resource-saving and soilprotecting technologies into the agribusiness and create modern production facilities. The processes of cooperation and agro-industrial integration of agriculture and the processing industry, service industries, as well as trade and banking organizations are getting more and more developed.

Studies show that the main source of investment in the agribusiness at the federal level is fund allocations from the development budget on a repayable basis under the guarantees of the government of the Russian Federation, provided on a competitive basis. In this case, there should be strict requirements for evaluating the effectiveness of investment projects and deadlines for documents being under consideration in federal ministries and departments. However, under the established regulations, many agricultural organizations, enterprises, and peasant economies may have no access to these funds.

Therefore, it is advisable to establish a special fund for long-term lending to agribusiness enterprises and organizations. At that, international investment should play an important role, and all the necessary conditions should be created to attract such investments. It should be noted that the agribusiness makes a significant contribution to the formation of the country's gross domestic product and the revenue part of the federal budget being not just a consumer of budget funds. These funds mainly support elite seed, breeding, and other farms that determine scientific and technical progress in the industry (Fig. 1).

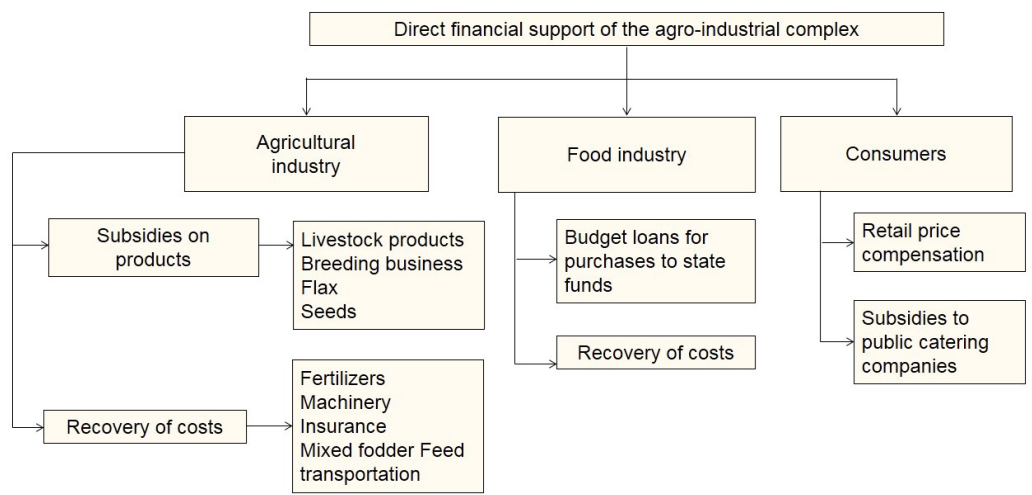




\section{Figure 1. The system of direct financial support to the agribusiness in the Russian Federation. (Own elaboration).}

Recognizing the need to save public expenditures, it seems appropriate to align the allocation of funds to the agribusiness, its contribution to the creation of the country's gross domestic product. Besides, solving the problem of price disparity will affect not only financial stabilization in rural areas but also the revival of investment activity in the agribusiness, the restoration and further development of domestic agricultural machinery and chemical industry.

The regulation of rates of import customs duties and the establishment of food quotas are one of the measures of state support and protection of agricultural producers. The introduction of compensatory customs duties on certain food products and the simultaneous reduction of customs rates on imports of advanced technologies, new machinery and equipment are provided for in the relevant statutory and regulatory enactments. Large reserves for the developing production, reducing costs, and increasing revenues are also available to very commodity producers, who can solve their problems by creating various integration structures, from simple forms of integrating enterprises and organizations to the creation of holdings, as well as financial and industrial groups.

Recently, the integration of livestock producers with processing and feed enterprises, service organizations, trade, and financial structures have gained traction. Crop insurance is also an important factor in sustainable agriculture. Due to the lack of an effective insurance system and insurance reserves of agricultural enterprises and organizations, their overdue accounts payable increases significantly. Lean years are characterized by difficulties in placing credit resources, and the repayment of loans is not provided.

The practice has shown that the country's food security is directly dependent on strategic issues of agribusiness development, which include strengthening the state support of agricultural production, protection of the internal market, engineering and technological renewal of enterprises, and development of investment activities. Besides, economic growth in agriculture will revive the work of enterprises in other industries. Avoiding a collapse in agricultural production and food production is possible largely due to the rational use of agribusiness regulation forms and methods (Fig. $2)$. 


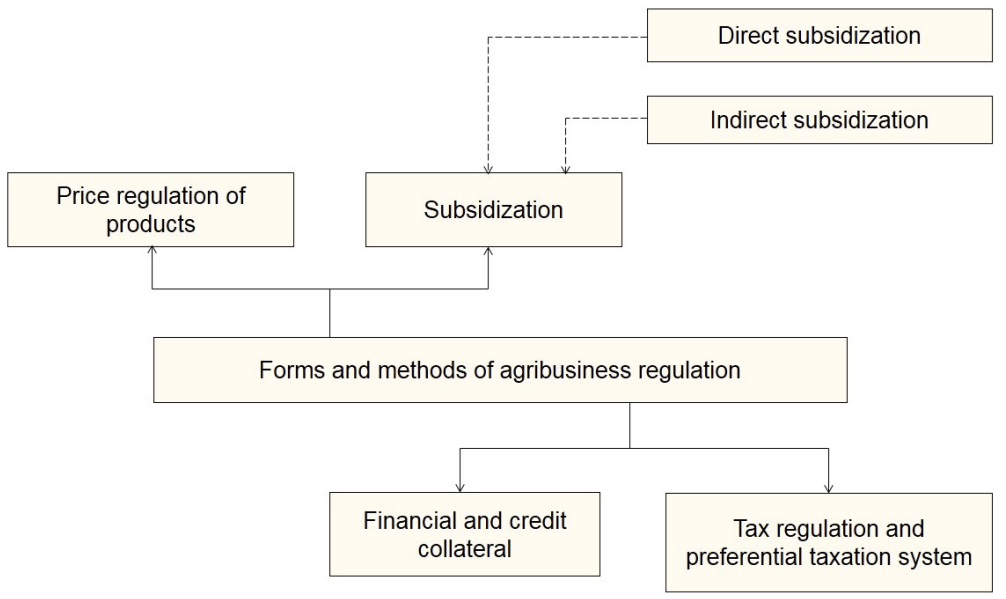

\section{Figure 2. Main forms and methods of agro-industrial production regulation (Own elaboration).}

Thus, with the general decline in the role of the state in the formation of market relations in the country, the agricultural sector of the economy should remain in the scope of state levers and market incentives. Besides, the government of the Russian Federation needs to develop a state target program for restoring and improving land fertility. The formation of effective land management models depends on these documents. At the same time, other conditions being equal, peasant farms are economically efficient, but at present small peasant farms are not able to fully utilize advanced equipment and the latest technologies.

Research shows that large-scale agricultural production is more efficient since it uses all factors of production based on labor-, resource-, and energy-saving technologies. In developed countries, the agricultural sector is undergoing processes of production cooperation and integration. The authors are also convinced that Russia needs the development of large agricultural organizations, the creation of agricultural holdings, and concurrent strengthening of peasant farms.

However, in recent years, agribusiness has been focused on the development of the small-scale sector rather than large farms. Positive results were obtained only in the production of potatoes, vegetables, fruits, and milk. In the main, mistakes were made yet during the transformations, 
which negatively affected the results of the agribusiness. Many peasant farms have become involved in crop rotations of large organizations, using their infrastructure without participating in its restoration. Besides, these processes were accompanied by a violation of relations between agricultural and processing organizations, and deterioration in investment activity.

The reduction of production in the agribusiness has led to the deterioration in the population's nutrition. Given the reduction in per capita food consumption, the balance of food resources in the country is currently quite tense. To maintain a stable position in the food market, Russia needs imports. In this case, it is necessary to develop a program that should ensure the formation of the food market, taking into account, first of all, the possibilities of in-house production.

Shortly, domestic production will fully support domestic consumption of poultry meat, eggs, milk and dairy products, potatoes and vegetables. It is necessary to take measures to form specialized zones for the production of these products and implement reasonable trade protectionism that does not allow dumping prices from foreign importers on the domestic market. The government of the Russian Federation should support the technological re-equipment of organizations in the processing industry. This will help to increase the competitiveness of agricultural products.

In the short term, the Russian Federation will still need to import a variety of food, such as meat and meat products, sugar, and several others. However, even in this area, the situation can be improved. In this case, it is necessary to develop a strategy that would provide for improving land relations. It is planned to develop a targeted state program for restoring soil fertility focusing only on eco-friendly technologies. Therefore, agricultural policy should be based on strategic goals aimed at ensuring the transition from a decline in agricultural production to stabilization and growth, as well as the transformation of the country from importer to exporter of certain types of products and agricultural raw materials.

\section{Discussion}

The reliability of the presented approaches is confirmed by the fact that in the Russian Federation, in the course of implementing the agrarian reform, the resource, raw material, and food markets have become strongly monopolized (Mukhlynina et al., 2018; Nikiforov et al., 2018; Zavalko et al., 2018). The monopoly of the related industries of agriculture, a significant number of intermediaries in the non-intervention of the state have led to a sharp price disparity, redistribution of the surplus product created in the agriculture in favor of monopolists, intermediaries, and eventually to the 
Zoya Ivanovna Latysheva, Elena Viktorovna Skripkina, Natalia Alekseevna Kopteva, Dmitri Ivanovich Zhilyakov y Andrey Igorevich Nikiforov

decline in the rehabilitation of production in the basic sector of agriculture.

At the same time, the formation of a competitive environment in all agricultural markets will contribute to the redistribution of the final income of the agribusiness in proportion to the costs of all constituent links. Besides, a legislative framework is needed to strengthen the role of the state in regulating the activities of organizations in the energy sector, transport, and communications to eliminate price disparity. The operation of the commodity exchanges should be restored as well.

It is also necessary to support the sustainable economic growth of the agribusiness, create conditions for the adaptation of producers to market conditions. An important function of state regulation in this regard is to maintain a consistent demand for food and agricultural raw materials. The country's budget should provide for the financing of investment projects. First of all, these should be projects aimed at the development of viticulture and winemaking, processing of crop and livestock products, selection and seed production, restoration of soil fertility, as well as agricultural engineering. The state should contribute to the formation of effective demand of the population, affecting the formation of incomes of the main groups of the population through the regulation of the price system for agricultural products, state orders, and food purchases to federal and regional food funds.

\section{Conclusion}

Summing up, one should note that the state regulatory system of the agribusiness should be based on pursuing a policy of reasonable protectionism, ensuring food security through a system of customs tariffs and taxes on imported food products. It is necessary to create a favorable climate for foreign investors, as well as joint ventures in the agribusiness, and provide state guarantees for foreign creditors when importing advanced equipment and technology, as well as finance key areas of science on the problems of the agribusiness.

Besides, agricultural price parity should include parity with consumer prices for rural residents. Wages of employees in rural areas should ensure the reproduction of labor power and the development of the social sphere. At the federal level, it is necessary to regulate prices for basic agricultural products, such as meat, milk, flour, and eggs. Prices for vegetables, fruits, and other agricultural products should be set at the municipal and city levels. 


\section{Bibliographic References}

DEMKINA NADEZHDA, Ibragimovna; KOSTIKOV PAVEL, Alekseevich; LEBEDEV KOSTYANTYN, Anatol'evich. 2019. "Formation of professional competence of future specialists in the field of information environment" In: Revista Espacios. Vol. 40, No. 23, p. 3.

KOLESNIK NATALIA, Fedorovna; AKASHEVA VALENTINA, Vyacheslavovna; SHIBILEVA OLGA, Viktorovna. 2020. “Analiz uslovij funkcionirovaniya fermerskih hozyajstv $v$ hode realizacii nacional'nyh proektov [Analysis of the functioning conditions of private farms during the implementation of national projects]" In: Bulletin of the Tatishchev Volga State University, Vol. 2, No.1, pp. 106-113.

MALTSEVA, Ya.V. 2019. "Sravnitel'nyj analiz metodov upravleniya zemel'nymi resursami [Comparative analysis of land resources management methods]" In: Alley of Science, Vol. 2, No. 29, pp. 266270.

MUKHLYNINA MARIA, Mikhailovna; SHISHANOVA ELENA, Ivanovna; NIKIFOROV ANDREY, Igorevich; RYAZANOVA NATALYA, Yevgenievna; LEBEDEV KOSTYANTYN, Anatol'evich. 2018. "Economic and legal aspects of environmental protection when using artificial water bodies" In: Journal of Environmental Management and Tourism. Vol. 9, No. 27, pp. 633-638.

NIKIFOROV ANDREY, Igorevich; RYAZANOVA NATALYA, Yevgenievna; SHISHANOVA ELENA, Ivanovna; LYZHIN DMITRY, Nikolaevich; LEBEDEVA OLGA, Yevgenievna. 2018. "Economic and legal support for the use of coastal territories in a tourism-recreation sector" In: International Journal of Civil Engineering and Technology. Vol. 9, No.13, pp. 1048-1054.

NIKOLSKAYA ELENA, Yurievna; KOVALEVA NATALIA, Iosifovna; USPENSKAYA MARINA, Evgenjevna; MAKSHAKOVA NATALIA, Ivanovna; LYSOIVANENKO ELENA, Nikolaevna; LEBEDEV KOSTYANTYN, Anatol'evich. 2018. "Innovative quality improvements in hotel services" In: European Research Studies Journal. Vol. 21, No. 2, pp. 489-498.

RAKHMATULLIN YULAY, Yalkinovich; AKHMEDINA GULNUR, Badretdinova; KUZYASHEV AZAT, Nurgaleevich; NASRETDINOVA ZULFIYA, Tabrisovna. 2020. "Vliyanie subsidii na formirovanie 
Zoya Ivanovna Latysheva, Elena Viktorovna Skripkina, Natalia Alekseevna Kopteva, Dmitri Ivanovich Zhilyakov y Andrey Igorevich Nikiforov

126 Improving the State Regulatory System of The Agribusiness

finansovyh rezul'tatov v sel'skom hozyajstve [Influence of subsidies on the formation of financial results in agriculture]" In: Business. Education. Right. Vol. 1, No. 50, pp. 204-208.

SEMYASHKIN, E.G. 2019. "Eksport produkcii APK Rossii: tekushchee razvitie i trendy [Export of agricultural products of Russian agribusiness: Current development and trends]" In: The economy of Agricultural and Processing Enterprises. No. 4, pp. 33-36.

SHAKHMAMETEV ALEXEY, Alimovich; STRELETS IRINA, Aleksandrovna; LEBEDEV KOSTYANTYN, Anatol'evich. 2018. "Strategic mechanisms for the future development of the international e-commerce marker" In: Revista Espacios. Vol. 39, No. 27, p. 21.

TEUNAEV AKHMAT, Seit-Umarovich. 2019. "Aktual'nye voprosy preduprezhdeniya prestupnosti $\mathrm{v}$ sfere subsidirovaniya agropromyshlennogo kompleksa [Key considerations of crime prevention in the subsidizing the agribusiness]" In: Bulletin of the Ufa Law Institute of the Ministry of Internal Affairs of Russia. Vol. 1, No. 83, pp. 36-43.

UNYAEWA, R.R; KLEMANOV, I.V. 2020. "Osobennosti regional'nogo razvitiya sub” ekta RF na osnove optimizacii gosudarstvennoj politiki APK [Features of regional development of the Russian Federation entity based on optimization of the state policy of agribusiness]" In: Regional Economy: Theory and Practice. Vol. 18-1, No. 472, pp. 165178 .

ZAVALKO NATALIA, Aleksandrovna; KOZHINA VERONIKA, Olegovna; KOVALEVA OKSANA, Petrovna; KOLUPAEV ROMAN, Vladimirovich; LEBEDEVA OLGA, Yevgenievna. 2018. "System approach to diagnostics and early prevention of a financial crisis at an enterprise" In: Journal of Applied Economic Sciences. Vol. 13-1, No. 55, pp. 84-88. 
Vol. $37 \mathrm{~N}^{\circ} 65$

Esta revista fue editada en formato digital y publicada en julio de 2020, por el Fondo Editorial Serbiluz, Universidad del Zulia. Maracaibo-Venezuela 